\title{
PREDISPOSING, ENABLING, AND REINFORCING FACTORS THAT INFLUENCE FULL BASIC IMMUNIZATION COVERAGE IN BANGKALAN DISTRICT, MADURA ISLAND IN 2017
}

\author{
Lidia Aditama Putri ${ }^{1}$, Bhisma Murti ${ }^{2}$, Dini Setiarsih ${ }^{3}$, Widiharti ${ }^{4}$, Wiwik Widiyawati ${ }^{5}$, Diah Jerita Eka Sari $^{6}$, \\ Nourma Yunita ${ }^{7}$ and Endah Mulyani ${ }^{8}$ \\ 1,7,8 Department of Midwifery, Faculty of Health, Universitas Muhammadiyah Gresik, Indonesia \\ ${ }^{2}$ Faculty of Postgraduate Program, Universitas Sebelas Maret, Surakarta, Indonesia \\ ${ }^{3}$ Doctoral Program in Faculty of Medicine, Public Health, and Nursing; Universitas Gadjah Mada, Yogyakarta Indonesia \\ 4,5,6 Department of Nursing, Faculty of Health, Universitas Muhammadiyah Gresik, IIndonesia \\ ${ }^{5}$ Doctoral Program in Faculty of Public Health, Universitas Airlangga, Surabaya, Surabaya, Indonesia
}

Coresponding author: Lidia Aditama Putri.

Email: liydyaputri@umg.ac.id

\begin{abstract}
The cases of morbidity and mortality of babies and toddlers are continue to occur because of negligence of the mothers in providing complete basic immunization to their babies. This study is a cross-sectional study that was conducted to identify the predisposing, enabling, and reinforcing factors that influence full basic immunization coverage. The study was performed on mothers who had 9-12 months old child spread in 22 villages, purposively selected through from 22 community health centers in Bangkalan District, Madura Island. 200 mothers were selected as the study's respondents. The data were collected through questionnaires and from the book of "Kesehatan Ibu dan Anak" (KIA). The result of the study was obtained using logistic regression statistical test and it showed that the factors that influenced of full basic immunization coverage in Bangkalan District, Madura Island, were family income as predisposing factor (OR=2.26; $95 \% \mathrm{Cl}=$ 1.14 to $4.51 ; p=0.020)$; health facility as enabling factor $(O R=3.03$; $95 \% C l=1.59$ to $5.80 ; p=0.001)$; and community leader support as reinforcing factor $(O R=2.56 ; 95 \% \mathrm{Cl}=1.33$ to $4.92 ; p=0.005)$.
\end{abstract}

Keywords: Immunization Coverage, Basic Immunization, Predisposing Factor, Enabling Factor, Reinforcing Factor

\section{INTRODUCTION}

The proper and regular administration of immunization on babies and toddlers are very essential to prevent the children from suffering from Vaccine-Preventable Diseases (VPD), such as hepatitis B, polio, TB (Tuberculosis), diphtheria, pertussis, tetanus, type $B$ influenza, and measles. ${ }^{1}$ Today, many people have not vaccinated their babies and toddlers, this shall be a serious concern because the child's morbidity and mortality may increase due to VPD.

Based on the data reported by World Health Organization $(2017)^{2}$, there were about 19.4 million babies all around the world not get the full basic immunization and $60 \%$ of the babies live in 10 countries, including Indonesia. In Indonesia, the proportion of full basic immunization in 2015 was only $86.5 \%$ and it was not reached the national target (91\%). The proportion for Universal Child Immunization ( $\mathrm{UCl})$ Villages in Indonesia in 2015 was $82.2 \%$ and it was not reached the national target as well at $84 \%^{3}$
The full basic immunization coverage in 2016 in Bangkalan District was $72 \%$. This rate decreased from the previous year at $77.57 \%$. The UCI Villages achievement in Bangkalan District also decreased in the past 4 years, which was $71.9 \%$ in $2013,71.5 \%$ in $2014,65.1 \%$ in 2015 , and $50.2 \%$ in 2016 ; while the expected target of the UCI Village was $84 \% .4,5$

One of the impacts that emerged from the decrease of full basic immunization rate in Bangkalan District was the occurrence of many VPDs in Bangkalan District throughout the year of 2015, which were 45 measles cases, 3 Acute Flaccid Paralysis (AFP) cases, and even 19 diphtheria outbreak cases. ${ }^{4}$ In 2016, there were several VPD cases, they were 9 diphtheria outbreak cases, 12 tetanus neonatorum cases, 3 AFP cases, and 171 measles outbreak cases. ${ }^{5}$

Family income as the predisposing factor, health facility as the enabling factor, and community leader support as the reinforcing factor, are the theory that was introduced by Lawrence Green. That factors are contribute to prevent the full 
basic immunization coverage in Bangkalan District, Madura.

Bangkalan District is categorized as a district that is unable to run the immunization program well and the implementation is far from the target that has been set by the government. Bangkalan District has low family income, limited access to health facilities, and the people tend to comply with the village's chief, those are the factors that inhibit the target achievement of the full basic immunization.

This study aims to identify the predisposing, enabling, and reinforcing factors that influence full basic immunization coverage.

\section{METHODOLOGY}

\section{Study Design and Sampling}

This study was an observational-analytical study with a cross-sectional approach. The study was conducted on mothers who had 9-12 months old children and domiciled in Bangkalan District. The sampling technique was purposive sampling. There were 22 community health centers in Bangkalan district, therefore 9-10 subjects were taken from every community health centers that spread in Bangkalan. The Data were collect from August to October 2017. The inclusion criteria of this study were mothers who had 9-12 months old children, had KIA book, and literate. The samples within this study consisted of 200 respondents.

\section{Data Collection}

The data were collected with the assistance of the village midwives by visiting the house of mothers who had 9-12 months old child. The selected mothers were explained about the study and informed consent was signed. The data was collected by face-to-face interviews using standardized questionnaires.

The questionnaires were self-developed and validated through a pilot study using different samples from the current study with the Chonbach's Alpha of alpha 0.733 for health facilities and alpha 0.730 for community leader support. The data about respondent characteristics, family income, health facilities, and community leader support were taken by questionnaires. Meanwhile, the data about full basic immunization coverage were taken by looking at the immunization record book of "Kesehatan Ibu dan Anak" (KIA).

\section{Data Analysis}

The data were analyzed using IBM SPSS Statistic 22 application with a 95\% confidence level. The data about the respondent's characteristics were explained using frequency distribution. The data about family income, health facilities, and community leader support towards the effect on full basic immunization coverage were analyzed using logistic regression. All tests were two sided and result was considered as significant if $\mathrm{P}<0.05$.

\section{RESULTS}

Most of the respondents were > 35 years old $(91.5 \%)$ and had less than 3 children (67.0\%). Based on the baby's age, those who had the most full immunization states was 9 months old (39.5\%), then followed with 12 months old babies (22.5\%), 11 months old babies (20.0\%) and 10 months old babies $(18.0 \%)$. In terms of education, most of respondents had low education, consisted of 108 mothers who graduated from junior high school (54\%). Most of respondents of 136 mothers (68.0\%) did not work (housewife). All respondents were Moslem (100\%). The characteristics of respondents in Bangkalan District, Madura Island, are detailed in Table 1.

Table 1 also showed that most of respondents had high family income (72.0\%). Most of respondents (61.5\%) claimed that they were able to reach health facilities with ease to have their babies vaccinated. Most of respondents (61.5\%) gained good support from the community leader in getting full basic immunization for their babies. There were 135 mothers (68\%) who had their babies vaccinated and 64 mothers (32\%) who did not.

Indonesia has a national program of basic immunization which regularly held for 0-12 months old babies. Table 2 displays the full immunization coverage within the national immunization program on the study's respondents. The result of the study showed that the highest immunization coverage was hepatitis B immunization for the newborns (93.5\%) and lowest immunization coverage were DPT-HB-Hib 3, Polio 4, IPV immunization
(78.5\%). 
Table 1: Characteristics of respondent's immunization coverage in Bangkalan Distric, Madura Island

\begin{tabular}{|c|c|c|}
\hline Characteristics & $\mathbf{N}$ & $\%$ \\
\hline Mother's Age & $27.24 \pm 4.56$ & \\
\hline$<35$ years & 183 & 91.5 \\
\hline$\geq 35$ years & 17 & 8.5 \\
\hline \multicolumn{3}{|l|}{ Number of Children } \\
\hline$<$ three & 134 & 67.0 \\
\hline$\geq$ three & 66 & 33.0 \\
\hline \multicolumn{3}{|l|}{ Child's age } \\
\hline 9 months & 79 & 39.5 \\
\hline 10 months & 36 & 18.0 \\
\hline 11 months & 40 & 20.0 \\
\hline 12 months & 45 & 22.5 \\
\hline \multicolumn{3}{|l|}{ Mother's education } \\
\hline$<\mathrm{SMA}$ & 108 & 54.0 \\
\hline$\geq S M A$ & 92 & 46.0 \\
\hline \multicolumn{3}{|l|}{ Mother's occupation } \\
\hline Employed & 64 & 32.0 \\
\hline Unemployed (Housewife) & 136 & 68.0 \\
\hline \multicolumn{3}{|l|}{ Mother's religion } \\
\hline Moslem & 200 & 100.0 \\
\hline Non-Moslem & 0 & 0.0 \\
\hline \multicolumn{3}{|l|}{ Family income ${ }^{*}$} \\
\hline Low family income & 56 & 28.0 \\
\hline High family income & 144 & 72.0 \\
\hline \multicolumn{3}{|l|}{ Health Facility } \\
\hline Not reachable & 77 & 38.5 \\
\hline Reachable & 123 & 61.5 \\
\hline \multicolumn{3}{|l|}{ Community Leader Support } \\
\hline Insufficient & 77 & 38.5 \\
\hline Good & 123 & 61.5 \\
\hline \multicolumn{3}{|l|}{ Basic Immunization Coverage } \\
\hline Un-full Immunization & 64 & 32.0 \\
\hline Full Immunization & 136 & 68.0 \\
\hline \multicolumn{3}{|c|}{$\begin{array}{l}\text { "Family Income category: Low if }<\text { Regional Minimum Wage }(<\text { Rp. } 1,530,656.00) \text { and high if } \geq \text { Regional Minimum Wage }(\geq R p . \\
1,530,656.00)\end{array}$} \\
\hline National Immunization Schedule & Yes & $\%$ \\
\hline Hepatitis BO & 187 & 93.5 \\
\hline BCG, Polio 1 & 179 & 89.5 \\
\hline DPT-HB-Hib 1, Polio 2 & 170 & 85.0 \\
\hline DPT-HB-Hib 2, Polio 3 & 161 & 80.5 \\
\hline DPT-HB-Hib 3, Polio 4, IPV & 157 & 78.5 \\
\hline Measles & 181 & 90.5 \\
\hline
\end{tabular}

Table 3: Multivariate analysis of factors influencing factors for full basic immunization coverage

\begin{tabular}{lccccc}
\hline \multirow{2}{*}{ Variables } & \multirow{2}{*}{$\mathrm{SE}$} & \multirow{2}{*}{ OR } & \multicolumn{2}{c}{$\mathbf{9 5 \% \mathrm { Cl } \text { for odds ratio }}$} & \multirow{2}{*}{$\mathrm{P}$} \\
\cline { 4 - 5 } & & & Lower Bound & Upper Bound & \\
Family income & 0.352 & 2.26 & 1.14 & 4.51 & 0.020 \\
Health Facility & 0.331 & 3.03 & 1.59 & 5.80 & 0.001 \\
Community Leader Support & 0.335 & 2.56 & 1.33 & 4.92 & 0.005 \\
\hline
\end{tabular}


Table 3 showed the result of multivariate analysis on predisposing, enabling, and reinforcing factors that influence full basic immunization coverage in Bangkalan District, Madura Island. The result of multivariate analysis using logistic regression showed that there was the influence of family income as predisposing factor $(\mathrm{OR}=2.26 ; 95 \% \mathrm{Cl}=$ 1.14 to $4.51 ; p=0.020)$; health facility as enabling factor $(\mathrm{OR}=3.03 ; 95 \% \mathrm{Cl}=1.59$ to $5.80 ; \mathrm{p}=0.001)$; and community leader support as reinforcing factor $(\mathrm{OR}=2.56 ; 95 \% \mathrm{Cl}=1.33$ to $4.92 ; \mathrm{p}=0.005)$ towards the full basic immunization coverage in Bangkalan District, Madura Island.

\section{DISCUSSION}

Family income, as the predisposing factor, affected the achievement of full basic immunization coverage. According to Green and Kreuter (2000), the predisposing factor is a factor within an individual's self which eases someone in doing something, such as knowledge, attitude, education, socioeconomic, and etc. ${ }^{6}$

The result of the study showed that family income affected the full basic immunization coverage in Bangkalan District, Madura Island (OR=2.26; 95\% $\mathrm{Cl}=1.14$ to $4.51 ; \mathrm{p}=0.020$ ). Mothers with a high family income have 2.26 times bigger possibility to give full basic immunization to their babies compared to mothers with low family income. Therefore, when the family income is higher the possibility of the respondent to have full basic immunization for the children is also bigger. Respondents with higher family income would be more aware of their babies' health because they generally have fulfilled their primary family needs, such as food, cloth, and house. Thus, they will provide full basic immunization to their babies as an effort to preserve health. Another possible reason is mothers who have a higher family income generally have a better level of education and knowledge about immunization, so this affects the mother's decision to provide a complete basic immunization to her baby. These reasons have been agreed, as research conducted in Malaysia. ${ }^{7}$

The other than that, most of respondents within this study gained the family income from the husband. This was proven by the data that most of respondents, 136 mothers (68\%) did not work. Thus, respondents have more time to come to the health center to vaccinate their babies on time.

In many studies, family economic status has a significant effect on the full basic immunization coverage. ${ }^{8-11}$ The babies who were born in a high economic level they have a bigger chance to get immunization compared to babies who were born in low economic status. ${ }^{12}$ This might be because children who were born in a low economy family have more difficult access to reach the health center compared to those who were born in a high economy family. ${ }^{13}$

Health facility as an enabling factor did influence the full basic immunization coverage as well. Enabling factor is a factor that enables or facilitates the occurrence of a behavior, like the health facilities: hospital, drugs, and etc. ${ }^{6}$ In this study, the health facility factor was used as a study material as well. The result showed that health facility has an effect on full basic immunization coverage in Bangkalan District, Madura Island with $\mathrm{OR}=3.03 ; 95 \% \mathrm{Cl}=1.59$ to 5.80 ; and $\mathrm{p}=0.001$.

Accessible and sufficient health facilities are an important factor which can increase the immunization coverage to babies. Accessible health facility may increase the immunization status of 3-time folds. Respondents who can easily access the health facility because close distance $(<4 \mathrm{~km})$, a health facility that is available in every village, and community health center that actively holds regular and monthly activities are factors that are related with health facility and they can improve the chances of these mothers to vaccinate their babies. This finding agrees with the other studies that were carried out in Ethiopia, Nigeria, and Kenya. ${ }^{8,14-16}$

The decision of the mother to give their babies immunization in full and on time was influenced by the mother's experience in looking for a health facility. Mothers who found it difficult to reach the health facility have a lesser possibility not to vaccinate their babies. This can be commonly found in mothers who live in rural areas in which health facilities are rarely found unless they go to the urban area to get the immunization. This finding confirms the previous findings which claimed that accessible and sufficient health facility are factors that affect a mother's decision in giving immunization to the babies or not. ${ }^{17,18}$

The support from the community leader is a reinforcing factor that also influences the full basic coverage immunization. Green and Kreuter (2000). ${ }^{6}$ defined reinforcing factor as an external factor that strengthens the occurrence of a behavior, such as an attitude and behavior of a community figure, medical staff, family support, information/media exposure, law, etc.

Community leader supports such as from the religious leaders, the village chief, and/or important figures who live around the respondent's 
residence significantly affected the full basic immunization coverage $(\mathrm{OR}=2.56 ; 95 \% \mathrm{Cl}=1.33$ to 4.92; $p=0.005)$. The people of Madura have been well known as a society that greatly obeys the community leader, especially the religious leader. Thus, every word spoken by the community leader about immunization will greatly affect the respondents' decision in giving immunization to the baby or not.

Mothers who gained positive support from the community leader to do immunization to their babies have 2.56 bigger chances to get immunization than the babies compared to those who did not gain positive support from the community leader. The study that was conducted by Lam WY, Lep Ż $(2018)^{10}$ also showed a similar result that community leaders greatly affected the decision of the mothers whether they want to get immunization for the children or not.

\section{CONCLUSION}

Family income as the predisposing factor, health facility as the enabling factor, and community leader support as the reinforcing factor, have the influence full coverage basic immunization to 9-12 months old babies. Mothers with high family income have 2.26 times bigger chance to give their babies a full basic immunization compared to those who have low family income. Mothers who can easily reach out to the health facility have 3 times bigger chance to give their babies a full basic immunization compared to those who have difficult access to reach it. Mothers who gain positive support from the community leader to do immunization have 2.56 times bigger chance to give full basic immunization to the babies compared to those who do not gain positive support from the community leader.

\section{LIMITATION}

The limitation in this study is the small subjects due to limited research resource and time before submitting the final report.

\section{ACKNOWLEDGEMENT}

The authors appreciate the Faculty of Post Graduate Program Sebelas Maret Univesity to give the permission to conduct this study. Last but not least, we thank all the respondents who participated in this study.

\section{CONFLICT OF INTEREST}

Authors declare no conflicts of interest.

\section{ETHICAL CONSIDERATION}

This study was approved by The Health Research Ethics Committee Dr. Moewardi General Hospital
School of the Medicine Sebelas Maret University of Surakarta (815/VIII/HREC/2017).

\section{REFERENCES}

1. Direktorat Surveilens, Imunisasi, Karantina dan Kesehatan Matra Direktorat DJP \& PKR. Program Imunisasi Ibu Hamil, Bayi, dan Balita di Indonesia. 2015:23-25.

2. World Health Organization. Immunization Coverage. Fact sheet $N$ 378. 2015:1. http://www. who.int/mediacentre/factshe ets/fs378/en/.

3. Kementerian Kesehatan RI. Situasi Imunisasi di Indonesia. 2016:1-11. doi:ISSN 2442-7659

4. DINKES Kab. Bangkalan. Profil Kesehatan Kabupaten Bangkalan Tahun 2015. Bangkalan: Dinas Kesehatan Kabupaten Bangkalan; 2015. www.depkes.go.id/.../profil/PROFIL_KAB.. ./3526_Jatim_Kab_Bangkalan_2015.pdf.

5. DINKES Kab. Bangkalan. Profil Kesehatan Dinas Kesehatan Kabupaten Bangkalan Tahun 2016. Bangkalan: Dinas Kesehatan Kabupaten Bangkalan; 2016.

6. Green L, Kreuter M. Health Promotion Planning an Educational and Environmental Approach. $2^{\text {nd }}$ Edition. London: Mayfield Publishing Company; 2000.

7. Rohaizat Hassan M, Afham Azman M, Li Yong $C$, et al. Knowledge and Perception Towards Supplementary Immunization Activities (SIA) Among Mothers in Cheras, Kuala Lumpur. Malaysian J Public Heal Med. 2019;19(2):126-131.

8. Girmay A, Dadi AF. Full Immunization Coverage and Associated Factors among Children Aged 12-23 Months in a Hard-toReach Areas of Ethiopia. Int J Pediatr. 2019;1-8. doi:10.1155/2019/1924941

9. Lakew Y, Bekele A, Biadgilign S. Factors Influencing Full Immunization Coverage Among 12-23 Months of Age Children in Ethiopia: Evidence from The National Demographic and Health Survey in 2011. BMC Public Health. 2015;15(1):728. doi:10.1186/s12889-015-2078-6

10. Lam WY, Lep Ž. Parental Decision-Making on Childhood Vaccination. 2018;9(June):114. doi:10.3389/fpsyg.2018.00735 
11. Hafid W, Martini S, Devy SR. Faktor Determinan Status Imunisasi Dasar Lengkap Pada Bayi di Puskesmas Konang dan Geger. J Wiyata. 2016;3(1):38-45. https://ojs.iik.ac.id/index.php/wiyata/art icle/download/69/68.

12. EFMoH. Ethiopia National Expanded Program on Immunization, Comprehensive Multi - Year Plan 2016 - 2020. Federal Ministry of Health, Addis Ababa, Ethiopia. 2015:1-115.

13. Abadura SA, Lerebo WT, Kulkarni U, Mekonnen ZA. Individual and Community Level Determinants of Childhood Full Immunization in Ethiopia: A Multilevel Analysis. BMC Public Health. 2015;15(1):972. doi:10.1186/s12889-0152315-z

14. Sibeudu FT, Uzochukwu BS, Onwujekwe OE. Rural-Urban Comparison of Routine Immunization Utilization and Its Determinants in Communities in Anambra States, Nigeria. SAGE Open Med. 2019;7:205031211882389.

doi:10.1177/2050312118823893

15. Kiptoo E. Factors Influencing Low Immunization Coverage Among Children Between 12 - 23 Months in East Pokot, Baringo Country, Kenya. Int $J$ Vaccines Vaccin. 2015;1(2):1-6. doi:10.15406/ijvv.2015.01.00012

16. Mbabazi W, Lako AK, Ngemera D, Laku R, Yehia M, Nshakira N. Maiden Immunization Coverage Survey in The Republic of South Sudan: A Cross-sectional Study Providing Baselines for Future Performance Measurement. Pan Afr Med J. 2013;16:1-8. doi:10.11604/pamj.2013.16.110.3164

17. Favin $M$, Steinglass R, Fields R, Banerjee $K$, Sawhney M. Why Children Are Not Vaccinated: A Review of The Grey Literature. Int Health. 2012;4(4):229-238. doi:10.1016/j.inhe.2012.07.004

18. Adedokun ST, Uthman OA, Adekanmbi VT, Wiysonge CS. Incomplete Childhood Immunization in Nigeria: A Multilevel Analysis of Individual and Contextual Factors. BMC Public Health. 2017;17(1):110. doi:10.1186/s12889-017-4137-7 